\title{
The Renminbi Exchange Rate Reform and Its Implications for Asian Markets
}

Takamoto Suzuki

\begin{abstract}
Up until now, the Renminbi (RMB) reform has been progressing gradually. With the RMB becoming a Special Drawing Right (SDR) component currency, China's monetary policies will exert significant influence on the international marketplace. The year 2014 witnessed the weakening of the RMB against the U.S. dollar, yet thanks to China's prudent economic policies, the RMB stopped depreciating further and remained quite stable for the first half of 2015, which benefited not only China itself, but also the United States, Japan, and other Asian economies. Asian markets used to be strongly influenced by the U.S. monetary policy and the performance of the U.S. dollar. However, since the RMB devaluation against U.S. dollar in the summer of 2015, Asian markets have been inclined to move in accordance with the market information from China rather than that from the United States. Although the RMB is not a currency like the euro that has been adopted by a number of countries, it can still exert great impacts on emerging economies in the world. For the RMB to take hold globally, improved fundamentals in emerging economies, an easing in the influence of the RMB-USD exchange rate, and a healthy financial system in China
\end{abstract}

Takamoto Suzuki is Economic Research Manager at Marubeni (China) Co., Ltd. 7th Floor, Tower Office, 2 Henderson Center, 18 Jian Guo Men Nei Avenue, Beijing 100005, China. He can also be reached at SUZUKI-T@marubeni.com.

(C) 2016 World Century Publishing Corporation and Shanghai Institutes for International Studies China Quarterly of International Strategic Studies, Vol. 2, No. 4, 485-506

DOI: $10.1142 / S 2377740016500317$ 
are all necessary. Meanwhile, both China and the United States need to enhance their coordination on macroeconomic policies and guarantee the stability of RMB-USD exchange rate.

Keywords: Renminbi (RMB) exchange rate; Special Drawing Right (SDR); economic pattern; Asian markets.

On October 1, 2016, the Renminbi (RMB) was added to the International Monetary Fund's (IMF) basket of currencies that make up the Special Drawing Rights (SDRs), the international reserve assets created by the IMF in 1969 to supplement IMF member countries' official reserves. As of the end of September 2016, the SDR basket consisted of the currencies of four developed economies: U.S. dollar (41.90 percent), euro (37.40 percent), Japanese yen (9.40 percent), and British pound (11.30 percent). Starting from October 1, it consists of the U.S. dollar (41.73 percent), euro (30.93 percent), Chinese yuan (10.92 percent), Japanese yen (8.33 percent), and British pound (8.09 percent). The RMB, an emerging economy's currency, has been added to the four developed economies' currencies, with the thirdlargest share following the U.S. dollar and the euro.

\section{Fluctuating RMB Exchange Rate Against the USD}

The RMB exchange rate regime has been undergoing major changes since the 1950s. From 1955 to 1971, the RMB was pegged at 2.4618 RMB to US $\$ 1$ under a fixed exchange rate system; after 1973, the RMB operated under a currency basket regime. In 1981, it reverted to a dual exchange rate system with an official exchange rate and a parallel internal trade settlement rate; however, the system was unified in 1994. In June 1995, a fixed exchange rate system was again effective, with the RMB fixed at 8.3 to US $\$ 1$ for ten years. Then in 2005, China moved to a managed floating exchange rate system using a basket of currencies as reference, so as to internationalize the RMB and make it more market-compatible. However, setbacks from the 2008 global financial crisis put the floating exchange rate system on hold, and prompted China to inject 4 trillion RMB into the economy. In June 2010, China ended its 4 trillion RMB fiscal policy and restarted the floating exchange rate regime based on a currency basket, aiming to further internationalize the RMB and make it more market-oriented. At the same time, China's GDP overtook that of Japan's. 
Table 1. Major RMB Rate Reforms (vs. U.S. Dollar).

\begin{tabular}{ll}
\hline 1-Jan-94 & Official and swap market rate converge at USD-CNY 8.70 \\
May-95 & USD-CNY de facto re-pegged at 8.30 \\
21-Jul-05 & CNY de-pegged from USD with $2.1 \%$ revaluation. Trading band at $+/-0.3 \%$ \\
18-May-07 & USD-CNY trading band widened to $+/-0.5 \%$ \\
1-Jul-08 & De facto re-peg around USD-CNY 6.83 \\
19-Jun-10 & De-peg from USD, CNY put on appreciation path \\
15-Mar-14 & USD-CNY trading band widened to $+/-2.0 \%$ \\
11-Aug-15 & USD-CNY fixing reform \\
11-Dec-15 & CFETS basket announced \\
\hline
\end{tabular}

Source: Standard Chartered Bank Global Research FX Alert 20, June 2016.

For a few years, the RMB grew stronger against the U.S. dollar, and the Chinese financial authorities said in March 2014 that they would allow a wider fluctuation range in the daily rate (parity rate) announced every morning. In August 2015, the authorities began considering the previous day's closing RMB-USD exchange rate in forming the official rate, rather than setting it at their own discretion to bring more market consistency to the RMB. China then shifted its focus from the bilateral RMB-USD exchange rate to an exchange rate based on a basket of currencies by introducing an $\mathrm{RMB}$ exchange rate composite index, so as to better maintain the stability of the RMB. In this way, China has been making progress toward internationalizing the RMB and linking it to market forces (see Table 1). Up to now, the RMB exchange rate reform has been promoted steadily to minimize its domestic impacts.

It is hopeful that further RMB exchange rate reform will be undertaken to amplify the currency's international influence, since it is now an SDR component currency. In this light, the RMB exchange rate and China's general monetary policies will have significant impacts on the international market. As head of the People's Bank of China comments, the inclusion of the RMB in the SDR basket of currencies is an opportunity to deepen financial reforms and open up China's financial markets, and it will also help promote world economic growth, protect the stability of the world's financial markets, and contribute to better global economic governance. ${ }^{1}$

${ }^{1}$ Statement by Zhou Xiaochuan, Governor of People's Bank of China, at the 31st International Monetary and Financial Committee (IMFC) meeting on April 18, 2015, http:// www.imf.org/External/spring/2015/imfc/statement/eng/chn.pdf. 
In other words, China's RMB reforms and monetary policies will seek to contribute to maintaining a stable global financial regime. The implication is that, like the U.S. dollar, the role of the RMB will be that of a responsible reserve currency. Yet a group of American scholars as well as former policymakers have made it clear that even with the RMB's inclusion in the SDR basket, the U.S. dollar will remain a dominant international reserve currency reflecting the U.S.'s economic scale and the freedom of its markets. ${ }^{2}$ This suggests a rivalry brewing, and that the United States believes there is a limit to the advancement of the RMB's position due to China's relatively closed political and economic system.

The reality is that by using the RMB for trade settlement and foreign direct investment (FDI) and by expanding the number of currencies used in its foreign exchange reserves, the RMB reform, including the RMB's internationalization and market compatibility, has been advanced. However, even as the RMB becomes more influential, we cannot see it either replacing or gaining parity with the U.S. dollar as the world's key currency, nor will the euro, yen or pound become currencies like the

Though included in the SDR basket, the RMB needs more progressive exchange rate reforms to become a major international reserve currency. U.S. dollar, which can be fully floated and undergo wide fluctuations.

In 2014, the RMB depreciated against the U.S. dollar, reflecting the gap in growth rates, interest rates, consumer prices and account balances between China and the United States, as well as the recovery of the U.S. economy and China's economic slowdown. The RMB could have depreciated further; however, it turned out to be quite stable thanks to China's prudent economic policies. In 2015 when the RMB once again began to depreciate, it was not only China, but also the United States, Japan, and the rest of Asia that expressed their desire for a stable RMB, because they were concerned about the risks a sharp plunge of the RMB would incur to the international markets. So, what might be the external effects of the RMB

2"A Symposium of Views: Will the Dollar Remain the Reserve Currency," The International Economy, Fall 2014, http://www.international-economy.com/TIE_F14_Reserve CurrencySymp.pdf. 
and China's foreign exchange and monetary policies? This question can be answered from a mid-term, macro-economic perspective.

\section{Process and Impacts of RMB Exchange Rate Reforms Since 2005}

China has had little experience with a fluctuating RMB in a world of many unknowns. In the decade after abandoning the dual exchange rate system in 1994, China experienced severe inflation due to its return to the international community and adoption of a "market economy with socialist characteristics," anxiety over the 1997 Asian financial crisis and its aftermath, and uncertainty about its future after entering the WTO in 2001. As such, it maintained a fixed exchange rate system. However, from July 2005 onwards, the $\mathrm{RMB}$ was allowed to move through a managed floating exchange rate system. After the 2008 financial crisis, the RMB was quickly put on an appreciation path against the U.S. dollar as part of its reform process (see Fig. 1).

A number of factors have contributed to a stronger RMB since July 2005. Fundamentally, China's economic growth rate was higher than that of the United States, which strengthened the appreciating tendency of the RMB against the U.S. dollar. More specifically, the appreciation of the RMB was due to: (A) bigger FDI inflow, rapid increase in exports, and China's surging current account surplus (see Fig. 2); and (B) corrective pressure on

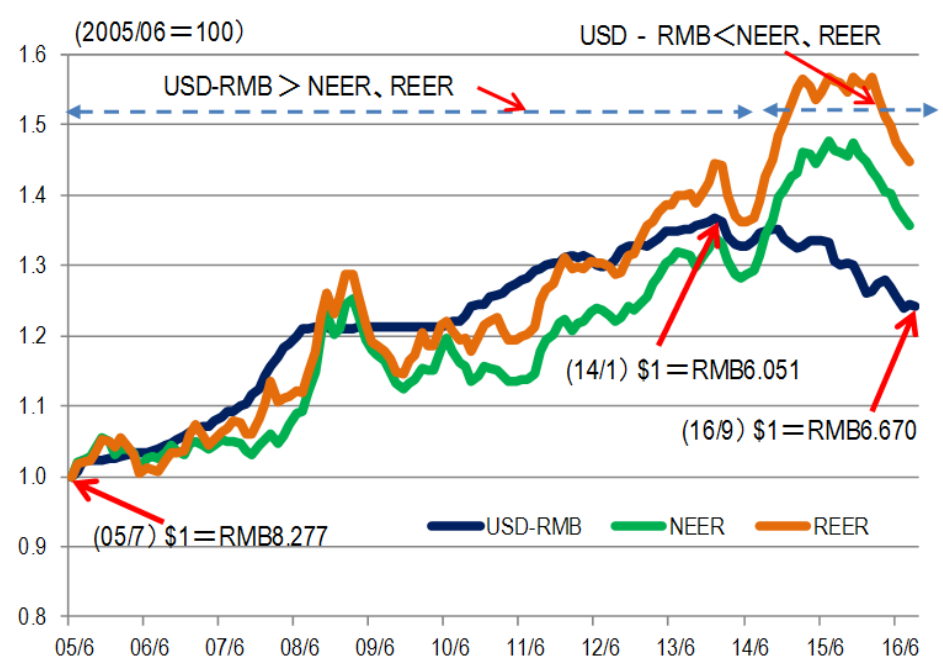

Fig. 1. RMB Exchange Rate vs. USD (Real and Nominal Effective Exchange Rates). Source: FRB, CEIC Data. 


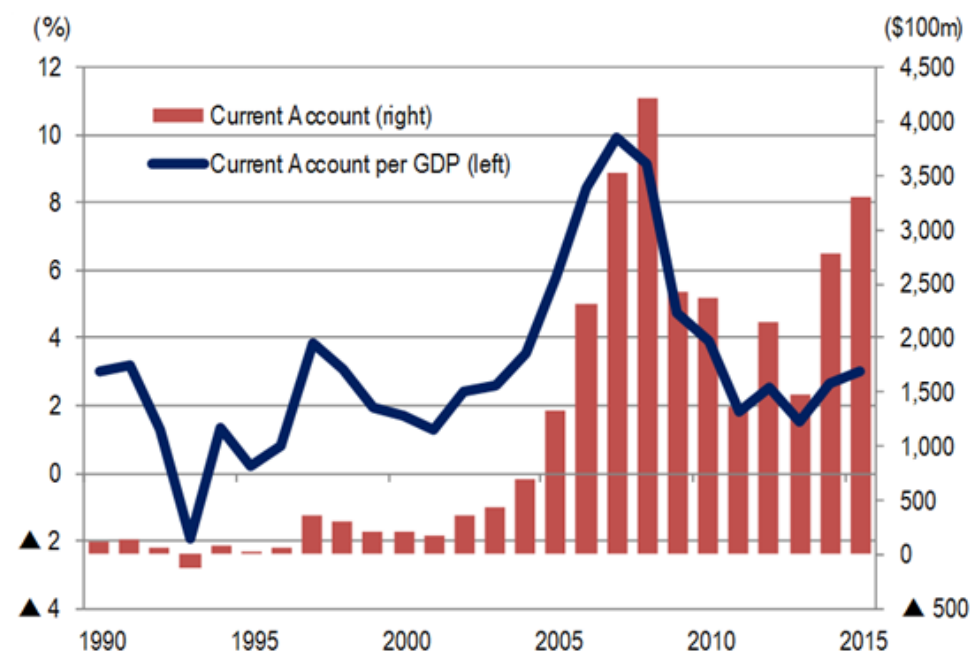

Fig. 2. China's Current Account Balance.

Source: State Administration of Foreign Exchange (SAFE), CEIC Data.

the ten-year fixed exchange rate system due to the Chinese economy's increasing dependence on external demand and the relative slowdown in consumption. The stronger RMB did not lead to the cooling of China's overheating economy, nor was there any shrinkage in the current account surplus. And, as a substitute for weaker exports to the United States, China's exports to the EU and emerging economies became robust, leading to a significant increase in the current account surplus. With growing expectations that the RMB would maintain its upward trend, investment continued to heat up. As there was little evidence of structural changes due to effects of a strong RMB, this situation went on until shortly before the 2008 global financial crisis.

It is important to understand the background of the RMB re-appreciation starting from June 2010. China pumped 4 trillion RMB fiscal stimuli into the economy between 2008 and 2010 in response to the financial crisis, but did not make adjustments to the previous over-investment, so it decided in 2010 that it was time to make necessary corrections to this investment situation. Besides, as the global recovery from the financial crisis was slightly delayed, promoting domestic consumption in China gained importance. In addition, after surpassing Japan as the world's second-largest economy, China found an overwhelming need to modernize and develop sound financial markets and systems both domestically and internationally. 
Another factor in the dynamics of the RMB-USD exchange rate is the real and nominal effective exchange rates of the RMB. In the mid-term, all the three rates tended to move in parallel; however, the RMB's real and nominal effective exchange rates showed a tendency of catching up with its regular rate rise. Following the 2008 financial crisis, values of the currencies of emerging economies fell sharply, and in 2013 they fell again due to the downturn in international commodity prices. However, the RMB remained strong during this period, and economies of emerging countries were also in good shape. China's export competitiveness improved as it found these new emerging markets.

The RMB remained strong against the U.S. dollar until 2013, as China's economic performance had been remarkable with continuous double-digit growth into 2011. As mentioned above, during the strong RMB period from 2005 to 2008, the aim was to cool the overheating economy and suppress the ensuing high inflation. At the same time, in terms of overall trade competitiveness, the real and nominal effective exchange rates (wider rates) rose; however, the pace of appreciation was much more moderate than that of the RMB against the U.S. dollar (narrower rate), so the overall effect on China's trade competitiveness was fairly mild - the RMB in fact fell against the euro and many emerging economy currencies. China was successful in the sense that exports to the EU and a number of emerging economies expanded. Conversely, from 2010 to 2013, world trade was stagnant and China sought to shift to an economic structure driven more by domestic demand. In addition, to seek an early escape from effects of the financial crisis amid lingering confidence and high domestic spirits developed through years of strong economic performance, China's financial authorities made the seemingly easy decision to push for appreciation of the RMB. However, as international currency markets were faced with a

A strong RMB from 2005 to 2013 was a result of China's robust economic growth and expanding exports. new set of problems, China began to implement a new RMB reform, and became more prudent and progressive in managing its foreign exchange and monetary policies.

After the 2008 financial crisis, the U.S. Federal Reserve carried out a series of quantitative easing (QE) measures labeled as Q1, Q2, and Q3, which ended with the specter of global money flowing into the 
United States. This is referred to as "risk off" in the international financial markets. Since the reform and opening-up in 1978, China has experienced high economic growth. However, this high growth was interrupted in 2012, as China's annual growth rate fell below 8 percent. In addition to the weak global economic recovery up until 2013, we saw the European sovereign debt crisis marked by continuing global financial instability. As a result, financial authorities in the United States, Japan, and Europe acted simultaneously on monetary easing and pumped money into the world's financial markets, which supported the stabilization of international financial and commodity markets. However, in 2014, as the U.S. economy recovered and employment reached the pre-crisis level, and many European countries no longer needed financial support programs to deal with the sovereign debt crisis, the United States hinted that it would normalize its monetary policies. In October 2014, the U.S. Federal Reserve put an end to its QE policy, and in December 2015 raised interest rates for the first time since the financial crisis.

The economic landscape in both China and the United States has also changed (see Fig. 3). On one hand, the growth rate disparity between the two countries has been greatly reduced; on the other hand, China's consumer prices vis-à-vis the United States have risen. These changes have reduced the price gap and increased the cost of living, which alleviates the upward pressure on the RMB versus the U.S. dollar. From another perspective, the Chinese economy is in a state of mild stagflation, while the U.S. economy has experienced stable growth and low inflation, suggesting that China's economy has deteriorated somewhat compared with the U.S. economy. This change has prompted global money to flow out of international financial and commodity markets, resulting in declining prices led by commodities and spurring depreciation of currencies in many emerging economies including the RMB. In 2014, the RMB again depreciated against the U.S. dollar. However, the real and nominal effective rates of the RMB continued to rise, as demonstrated in Fig. 2, up until early 2016. This movement was an indication of the normalization of U.S. monetary policy and the decline in global commodity prices from around 2013, which caused a prolonged economic slump in a number of emerging economies, but led to a boost in China's balance as it is a major commodity-importing country. 

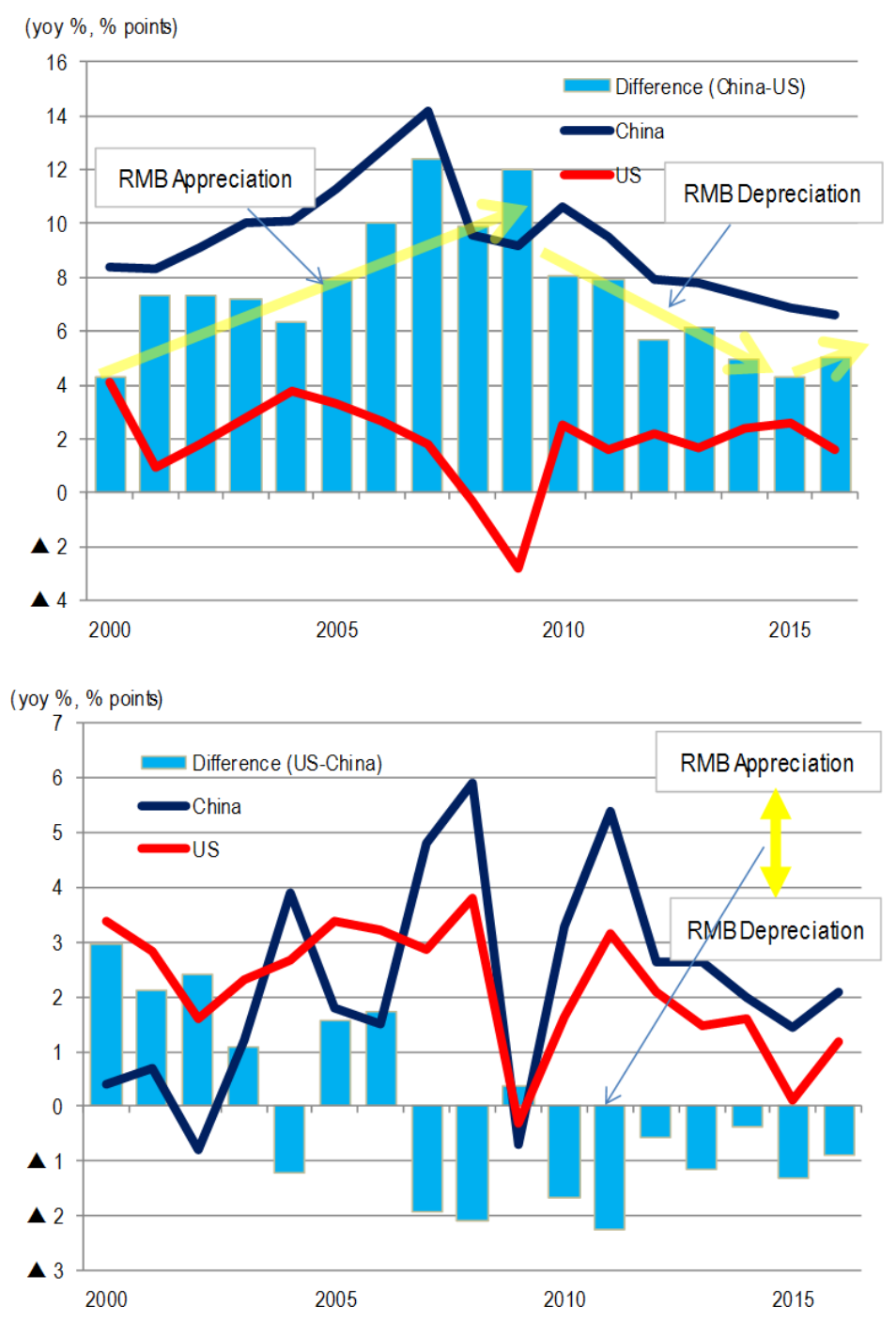

Fig. 3. China and U.S. Fundamentals.

Source: IMF.

In 2015, new trends in China's economy began to emerge. First, there was pressure on China's domestic economic restructuring, while at the same time China's export competitiveness was falling compared with other emerging economies, especially those in Asia, making a protracted slowdown in the Chinese economy all but inevitable. As the government's economic growth targets fell below expectations, the real and nominal effective exchange rates began to finally fall along with the RMB-USD rate. 
Second, as China has been projected to be the world's second-largest economy, the management of its economy as a whole, including the RMB, needs to be more transparent, so the RMB reform has to be promoted. Recent assessments by the IMF, World Bank, and other international financial institutions also concluded that the current RMB-USD rate is appropriate and that the round of appreciation should be over. Furthermore, China has stabilized the RMB, improved the RMB's international position, established the Asian Infrastructure Investment Bank (AIIB), and formulated the "Belt and Road" Initiative, thus the idea that the RMB should be included in the SDR basket of currencies was strengthened.

As such, the Chinese government actively lobbied for a review of the RMB in 2015. Actually, in the 2010 review of SDR currencies, China already sought the adoption of the RMB as an SDR component currency, when the RMB's use in trade settlement had just begun to increase. Later in the 2015 review, the United States reluctantly agreed to the RMB's adoption. The official reason was that the United States felt capital account liberalization linked to the RMB in China had not gone far enough (investment convertibility) and that China had carried out foreign exchange intervention, including verbal intervention. Yet the real reason was that the United States was worried that through the adoption of the RMB in the SDR basket, China was seeking a review of the U.S dollar as the key reserve currency. ${ }^{3}$

As can be seen from Table 1, the RMB's decline against the U.S. dollar became clear in 2015. The brakes were applied to the rise in real and nominal effective rates. Around the same time, the sentiment toward an interest rate hike was gaining popularity in the United States on the back of a stronger economy, while China's economy was decelerating, thus the expectations for further monetary easing and downward adjustment in the RMB-USD exchange rate were high. In Hong Kong, where the business climate is much freer than the Chinese mainland, the offshore RMB-USD

${ }^{3}$ On March 23, 2009, Zhou Xiaochuan, Governor of the People's Bank of China, put out a paper on the bank's homepage entitled "A Study of the International Currency System." It said that in the current international currency system, having the dollar as the key reserve currency was defective and that a new key reserve currency should be created that transcends national sovereignty. It said the new currency should make use of the SDR basket. However, on April 2 of the same year, the Xinhua News Agency came out with a commentary that stated "the paper by Zhou Xiaochuan on the international currency system has been misinterpreted," and that it was not a challenge to the current economic system. 
rate dropped prior to its falling on the mainland. For example, in August 2015 it depreciated by 2 percent more than it did on the mainland.

Given this situation, on August 11, 2015, the Chinese financial authorities lowered the official RMB-USD exchange rate by 1.9 percent based on the previous day's closing rate. The rate fell from US\$1 to 6.2 RMB to US $\$ 1$ to $6.3 \mathrm{RMB}$ in one day, and then fell to US $\$ 1$ to $6.4 \mathrm{RMB}$ over the next 12 days. This was a more than 3 percent drop. In this way, the gap between the mainland rate and the offshore rate narrowed. From the highest rate of US $\$ 1$ to 6.04 RMB recorded in January 2014 to the rate on August 17, 2015, the RMB depreciated by 5.5 percent. As the method to determine the RMB-USD exchange rate had been changed as part of the RMB reform, this devaluation continued to accelerate; and by October 2016, the RMB had depreciated by around 10 percent from its 2014 January high.

The RMB devaluation on August 11 was a result of the reform, in the way that the official RMB rate (the mid-rate between the highest and lowest rate of the day) announced every morning was formed, so that financial authorities could not arbitrarily determine the exchange rate and contribute to the RMB's internationalization and market compatibility. International financial institutions, organizations, and credit agencies welcomed the "RMB's heightened market inclusiveness," which brought the "RMB closer to being adopted as an SDR basket currency." The continued devaluation of the RMB has not yet been viewed as a problem. However, the Japanese media said the devaluation of the RMB by China this time would likely face international criticisms. Other countries' media remarked that the "RMB's movement in relation to the U.S. dollar was reflecting an economic slowdown" and showed "worries that Chinese economic deterioration was close at hand and would push commodity and stock prices down further," and that "this would lead to a wider race to devalue currencies." ${ }^{4}$

In terms of the August 11 RMB-USD exchange rate adjustment, if adjustments made from 2014 are included, the RMB dropped 10 percent against the U.S. dollar. (In comparison, from July 2005 to the end of 2013, it depreciated by one-third versus the dollar). While international financial institutions and organizations understood the logic behind the RMB-USD exchange rate adjustment, talks in the markets were fueling concerns. These

\footnotetext{
${ }^{4}$ Takamoto Suzuki, “World Currency and Stock Prices in Confusion - RMB Devaluation Ripple Effects," Marubeni Research Institute Report, August 21, 2015.
} 
worries first surfaced in the stock markets. Although a fairly solid economy was thought to have taken hold in the United States, U.S. exports to China were still weak. Moreover, it was observed that if the U.S. trade deficits were to expand, it was unlikely that further interest rate hikes would take place. As such, it was seen that the Chinese economy may be worse off than expected and the stocks of companies with much Chinese business, such as Apple, GM, Caterpillar, and KFC, began to sell off. Asian stock markets followed suit, suffering significant declines.

It is also observed that many stock markets in Asia peaked in April of 2015 and then entered a correction phase. The Chinese market continued to rise even as other Asian markets went into an adjustment phase, until it peaked on June 12 and embarked on its own correction course. Regarding the adjustments

The new round of RMB depreciation since 2014 led to high volatility in Asian stock markets. in Asian stock markets, although most of the capital outflows from these countries affecting their economies were related to the normalization of the U.S. monetary policy, in the two weeks following China's depreciation of the RMB on August 11, prices in the Shanghai stock market dropped by 33 percent, Korean 10 percent, Indonesian 14 percent, and Australian 10 percent. The volatility of these market movements contributed to a postponement of further interest rate hikes in the United States. However, Asian stock prices began to recover after the fall, so it seems the largest influence of RMB devaluation was on the corrections that took place in Asian stock markets from August to September in 2015.

The same thing also occurred in the currency markets. Figure 4 reveals market performances in some developed economies as well as Asian markets, with RMB devaluation against the U.S. dollar on August 11 as a starting point. According to this graph, such currencies of developed economies as the yen and euro rose 5 percent versus the dollar in the two months following the RMB's depreciation. Conversely, the Malaysian ringgit and the Indonesian rupiah fell by 13 percent and 8 percent respectively. However, by October 2016, the RMB's influence was no longer evident (Indonesian had risen by 5 percent), given that the RMB's depreciation from August 2015 to October 2016 was around 5 percent. The graph shows that it had a strong impact on the drop in the Malaysian ringgit and 


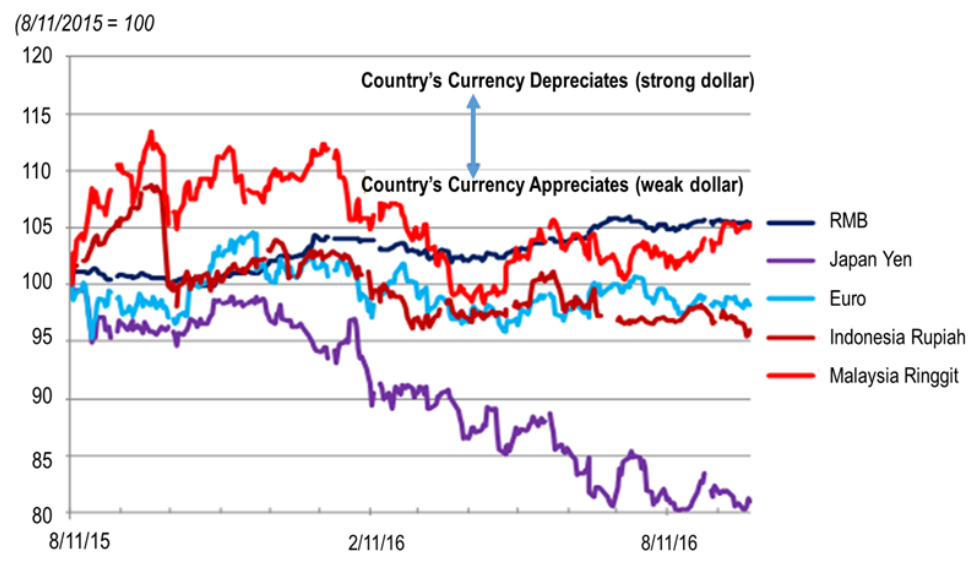

Fig. 4. Currency Movements of Selected Developed and Emerging Economies (August 2015-August 2016).

Source: FRB, CEIC.

Indonesian rupiah, among other Asian currencies, during August and September 2015.

\section{Revisiting the RMB's Role and China's Economic Weight in Asian Markets}

Traditionally, Asian stock and currency markets were strongly influenced by the U.S. monetary policy and the stability of the U.S. dollar. For many Asian countries, exports to the United States, dollar-dominated FDI, securities investments, and loans were key elements in their economic growth. Therefore, a worsening U.S. economy or a tightening U.S. monetary policy would reduce global cash flows and depress economic growth in these countries. Opposingly, an upturn in the U.S. economy or easing in monetary policy would increase the supply of cash and boost these countries' economic growth. Thus Japan and Europe would often try to coordinate their economic policies with the United States; every morning, economic news media and financial institution foreign exchange reports in Asia would first report on the trends of the U.S. economy.

Nowadays, things have changed in Asian financial markets due to China's economic rise. China's economic and monetary policies have been increasingly influential on Asia's stock and currency markets since 2010. Not only has the Chinese economy become the second-largest in the world and the largest in Asia, but China has also surpassed the United States as 
the largest trading partner for most Asian economies. ${ }^{5}$ China's foreign exchange reserves garnered from money inflows soared from $\$ 200$ billion in 2010 to $\$ 300$ billion in 2011, while China's direct investment overseas exceeded $\$ 100$ billion. Now much of the news from the economy-related media and reports on foreign exchange by financial institutions is on China's money trends, which indicates the strengthening of China's influence on the stock and currency markets. For a long time, the U.S. approach to China was to urge the reform of the RMB; however, after the 2008 financial crisis, China has often expressed the possibility of selling off more than $\$ 1$ trillion U.S. government bonds it has held to decrease its foreign currency risks. ${ }^{6}$ This kind of posturing is also contributing to China's stronger influence on the markets.

Figure 5 indicates a view of the currency and stock markets from Asia's standpoint. The Asian markets such as China, Japan (China+1 hour), Singapore and Australia (China +2 hours) can receive information concerning U.S. market trends from the previous day, including the U.S Federal Open Market Committee (FOMC), employment statistics and other U.S. economic indicators, before they open. Thus, for one to two hours before the time they open, they can be strongly influenced by the information from the United States. Today, important statistics from China also begin to pour in and large movements in the Chinese market can be seen. In this way, Chinese economic and market directions have come to exert a strong influence on Asian markets as well. If nothing of magnitude occurs in the Chinese market, Asian markets tend to move conventionally in conjunction with the U.S. market. However, if there is a shock in the Chinese market, Asian markets will likely move in accordance with the market information from China rather than that from the United States. With regard to the current

${ }^{5}$ According to Standard Chartered Bank, in 2000 the United States was the No. 1 trading partner for 24 of 60 major countries surveyed, while China was the major trading partner of only one country. By 2010, China had become the major trading partner of 15 countries, while the United States was so for 13 countries, a reversal of positions. In 2015 China pulled far ahead as the leading trading partner with 26 countries, while the United States was the major trading partner of only 7.

${ }^{6}$ Chinese President Xi Jinping and other Chinese leaders frequently reiterate China's firm stance in consolidating the existing international order, including economic order. See, for example, Xi's speech at the 70 ${ }^{\text {th }}$ UN General Assembly, September 28, 2015, http://www. fmprc.gov.cn/mfa_eng/topics_665678/xjpdmgjxgsfwbcxlhgcl70znxlfh/t1304144.shtml. 


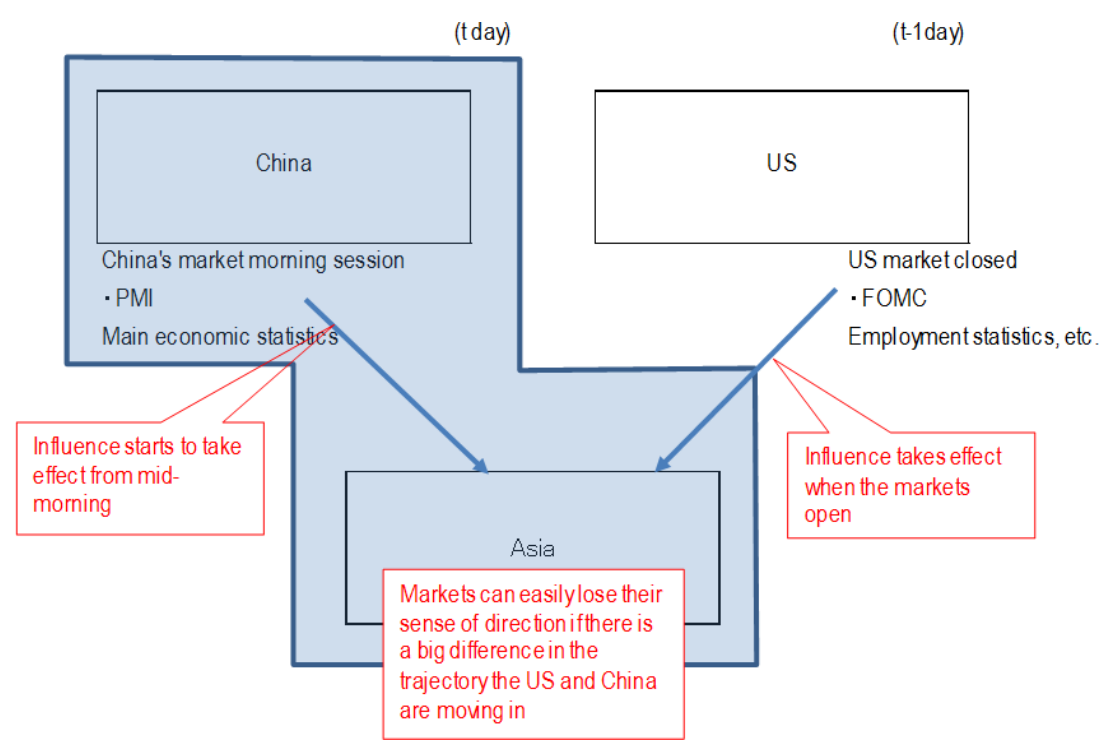

Fig. 5. How U.S. and Chinese Influence is Propagated on Asian Markets. Source: Marubeni (China) Co., Ltd.

situation, to stem the rapid current of global money outflows due to expectations of interest rate hikes in the United States and the forecast for a decelerating Chinese economy, emerging economies in Asia will have to tighten their monetary policies. ${ }^{7}$

In the two-month span from the RMB devaluation against the U.S. dollar, not only the tightening of the U.S. monetary policy and U.S. economic indicators affected Asia's financial markets, but the stability of Chinese economic policies and China's economic indicators also heavily impacted those markets. A sense of tightening in the U.S. policy and a sense of easing in Chinese policy can put strong pressure on Asia's financial markets to sell. A postponed U.S. monetary tightening policy on weaker overseas economic indicators and a stable U.S. economy can lessen the selloff pressure in Asian markets. After all, the U.S. Federal Reserve postponed further interest hikes in September 2015 after considering the weakness in overseas economies, which reduced worries over capital flows and the repatriation of money into the United States and cleared up the confusion

${ }^{7}$ The actual situation is that freedom in their monetary policies is severely restricted, so the fiscal policy and structural reform are increasingly important. The AIIB and the "Belt and Road" Initiative should be seen as a complement to this situation. 
over the previous two months. However, after two months of confusion, Asian financial markets began to seriously take note of China's currency movements and economic indicators, as it has become increasingly clear that any recurring fluctuations and changes in China could have significant impacts on Asia.

It is notable that in December 2015, China's financial authorities introduced the China Foreign Exchange Trade System (CFETS) RMB Index, a monetary policy management system that takes the currency exchange rate system a step further by using a basket of trading partner currencies with the real effective exchange rate basket as a reference, which could better determine the RMB's

Asian financial markets are increasingly sensitive to China's economic dynamics and monetary policies. strengths, weaknesses, and movements. Hence, the financial authorities will not only evaluate the RMB against the U.S. dollar, but also evaluate it against a comprehensive basket of currencies to show the RMB's genuine value. This measure gives the RMB more international appeal, transparency, and predictability with the overall intention of improving the stability of the RMB.

Entering into 2016, the RMB-USD exchange rate continued on a moderate downward trajectory, while the Japanese yen strengthened from JP $¥ 120$ to US\$1 to around JP $¥ 100$ to US\$1, with the RMB’s higher real and nominal effective exchange rates seeming to have corrected themselves. The slowing decline of China's foreign currency reserves since 2015 also indicated that the RMB was stabilizing. However, the RMB's downward trend was more pronounced in international markets, which was a reflection of anxiety over the Chinese economy's continuing slowdown. Knowing the RMB was going to join the SDR's basket of currencies in October, overseas financial institutions began buying Chinese government bonds. According to the China Central Depository \& Clearing Co., Ltd., net Chinese sovereign bonds buying for September was 41 billion RMB, three times the monthly average from the beginning of the year. Government bonds held by foreigners for the same month reached 385.97 billion RMB. Although the deep-rooted anxiety over a falling RMB versus the U.S. dollar subsided, it is likely to rise again gradually, as the RMB 
now is one of the official international currencies. Through August to September 2016, the U.S. economy and monetary policy moved in different directions from China's actual economic policy. This strengthened global money's risk aversion that led to depreciation of currencies in China's neighboring countries. In addition, China's real economic situation and its economic policies had an adverse effect on Asian - even the world's - stock and commodity markets.

From the economic cycles in the United States and China (see Table 2), it can be observed that the cycles were relatively aligned: RMB appreciation against the U.S. dollar which began in 2005 came to an end with the outbreak of the financial crisis, but then again strengthened from 2010. The RMB modestly appreciated during the economic expansion phase, due to the position of the U.S. economy as one of the backbones of the world economy and to China's efforts to prevent economic overheating and inflation. For the world, this served to maintain the economic boom. It was not until 2011 that the Chinese economy began to decelerate as moderate economic recovery in the United States continued. Still, it is likely that the U.S. and Chinese economic cycles will continue to overlap to some extent. As far as the U.S. economy goes, "the economic expansion phase that has

Table 2. U.S. and China's Business (Economic) Cycles.

\begin{tabular}{|c|c|c|c|c|c|}
\hline & \multicolumn{2}{|c|}{ US } & & \multicolumn{2}{|c|}{ China } \\
\hline & Low & Peak & & Low & Peak \\
\hline 3rd Cycle & 1970/11 & 1980/1 & 7th Cycle & 1982 & 1984 \\
\hline 4th Cycle & 1982/11 & 1990/7 & 8th Cycle & 1987 & 1987 \\
\hline 5th Cycle & $1991 / 3$ & $2001 / 3$ & 9th Cycle & 1991 & 1992 \\
\hline 6th Cycle & 2001/11 & 2007/12 & 10th Cycle & 2000 & 2007 \\
\hline 7th Cycle & $2009 / 6$ & - & 11th Cycle & 2009 & 2010 \\
\hline & & & 12th Cycle & - & \\
\hline
\end{tabular}

Source: Marubeni (China) Co., Ltd., and Xie San Ming, The Research of Growth Potential and Business Cycle of China's Economy, China Planning Press, 2001.

Note: China has announced quarterly economic growth rates since 1993. Up until the 10th cycle the low was taken from China Economic Growth Potential and Economic Cycle Research. The peak is the year when the growth hit its highest. The 11th cycle is an estimate taken from the economic situation at the time. 


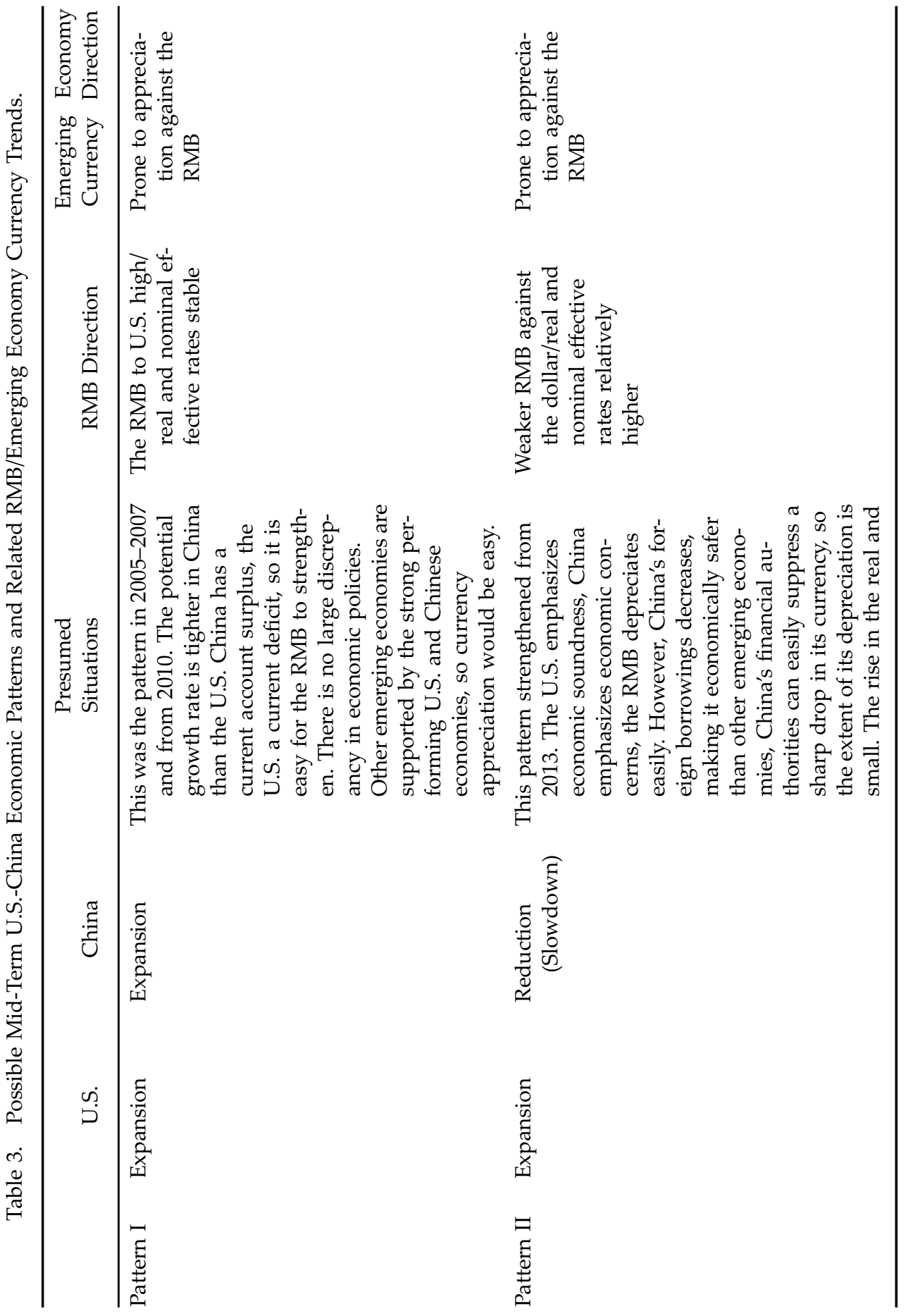




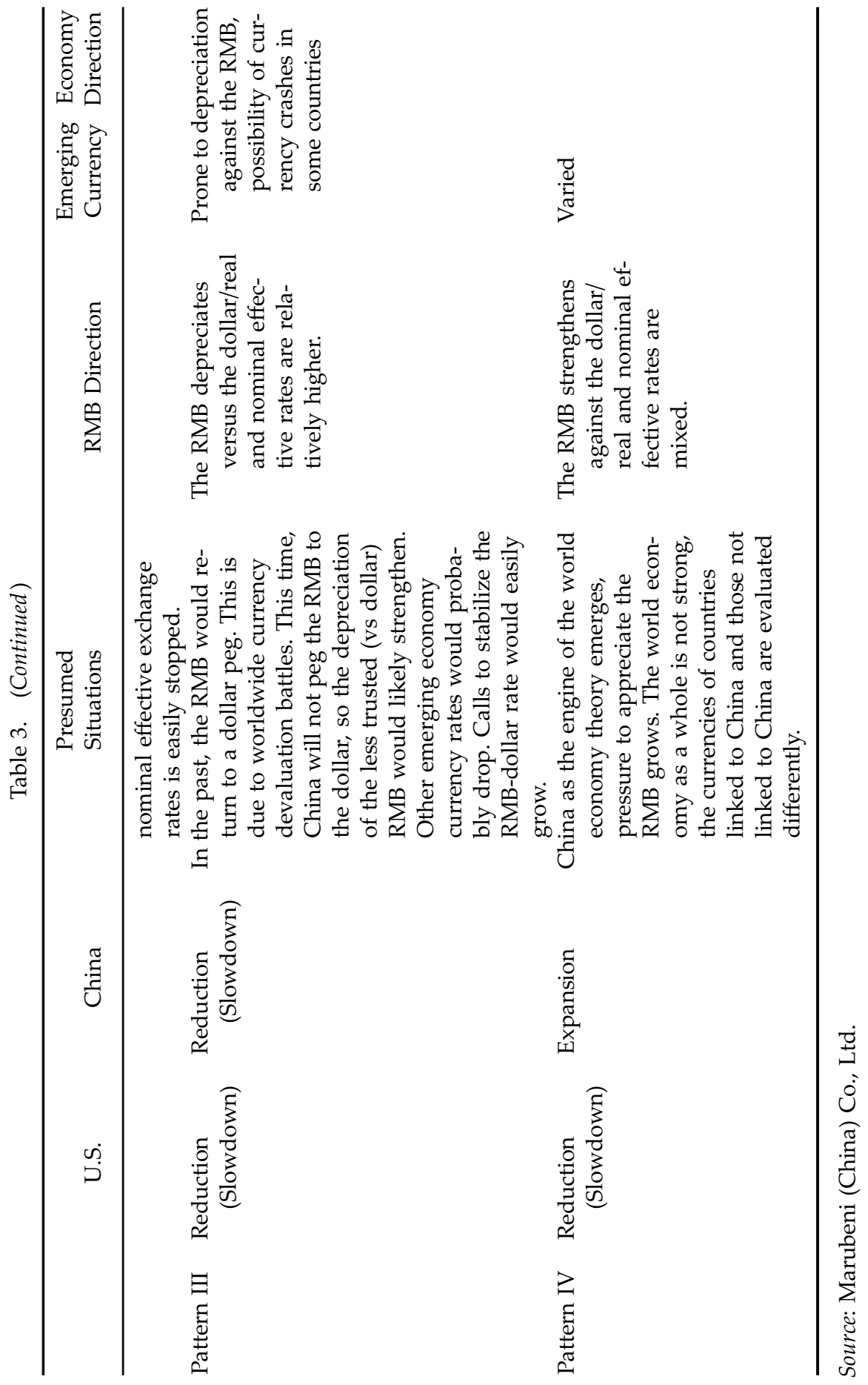


continued since 2009 is, in all probability over," with "interest rate hike implementation pressures subsiding," which will approach the same pattern as the slowing Chinese economy. Related to this, the predicted sharp plunge in the RMB-USD rate (weak RMB) in the second half of 2015 did not materialize, so pressure on the outflow of foreign exchange reserves from China was mitigated. However, if the U.S. and Chinese economies slow down at the same time, the RMB-USD exchange rate and currencies in China's neighboring countries will certainly begin to move. What kind of economic policy, in particular monetary policy, will these neighboring countries employ? Moreover, what will happen if the U.S. and China economic cycles do not overlap?

Possible U.S. and Chinese economic patterns in the mid-term and the potential trends of the RMB and currencies of some emerging economies in Asia for each situation are outlined in Table 3. In pattern I (both the U.S. and Chinese economies expand) and pattern II (the U.S. economy expands, while the Chinese economy slows) are conventional patterns that have been experienced. Pattern III (both the U.S. and Chinese economies slow down), and pattern IV (U.S. economy slows and the Chinese economy expands) are patterns that have not yet been witnessed, where the RMB-USD exchange rate is likely to undergo drastic fluctuation.

Pattern III requires special attention. If the U.S. and Chinese economies, which make up 40 percent of the world's GDP, were to slump at the same time and the lower trusted RMB were to be sold off, the world economy would shrink on a nominal dollar basis, in addition to the danger that currencies of some Asian economies - with little confidence in them - would be sold equivalent to or even more than the RMB, further shrinking the world economy in nominal dollar terms. In the confusion over the RMB's movement in August and September 2015, the fact was that an unstable RMB was seen as unfavorable worldwide. Therefore, it is believed that the RMB exchange rate regime should be reformed so that it can better correspond to the real economic power behind the RMB. Ideally, the RMB should have shifted to a full-floating system. However, the Chinese economy substantially supports many Asian economies, whose currencies are largely anchored by the RMB. Between the viewpoints that currencies of the most powerful economies should be floated and that anchor currencies 
should be stable, can a middle way be found for the RMB? We have yet to find the answer as the world is entering unknown waters.

China and the U.S. must work closely on macroeconomic and fiscal policies to keep the world markets stable.

\section{Conclusion}

The RMB is not a currency like the euro that has been adopted by a number of countries, but on the whole it has strong influence on emerging economies; as such, it could be considered as a key currency for emerging economies. China recognizes its international responsibility by both letting the RMB move freely and stabilizing it when necessary, which shows that the RMB is becoming a key currency. For the RMB to take hold globally, there are three major things that must be done by China and the world.

The first is to improve the fundamentals in emerging economies and to ease the influence of the RMB-USD exchange rate.

The second is to promote a healthy financial system in China to alleviate anxiety over the RMB. For one thing, transparency of the RMB must be enhanced. Currently, the CEFTS RMB Index has been employed, and in the first quarterly currency policy report of 2016, forward guidance has also been introduced in the RMB market, and financial authorities are trying to find a rate closer to the RMB's genuine value, one that better reflects its economic influence. For another, China's domestic debt problem, reflecting concerns over the stability of the RMB, needs to be solved. As Alfred Schipke, the IMF's Senior Resident Representative in Beijing, remarked, "reform is necessary to avoid a debt crisis in the long-term." ${ }^{8}$

The third is to strengthen cooperation and coordination between the U.S. and China with regard to the world's macro-economy in the short term. In this respect, multilateral dialogues take place in forums like the G20 Finance Ministers and Central Bank Governors from 1999 and the G20 Summit from 2008, and bilateral talks between the United States and China

${ }^{8}$ Wang Yanfei, “IMF Senior Official Says Restructuring is Essential for Country to Avoid Debt Crisis," China Daily, September 27, 2016, http://usa.chinadaily.com.cn/business/201609/27/content_26905897.htm. 
take place in the form of the Strategic and Economic Dialogue (S\&ED), which has been going on since 2008. The United States, through the abovementioned frameworks, has been urging China on issues such as trade and investment liberalization as well as currency reform, among others. Moreover, at the 2016 G20 Summit, China led the discussion around shifting from measures taken in the wake of the financial crisis to a focus on creating a sustainable world economic growth path, with each country applying whatever means they can to maintain growth.

Although it is important for the United States and China to cooperate in various ways and areas, this article has focused on approaches to understand the RMB-USD exchange rate. Needless to say, the United States and China should work together to manage their economies and carry out necessary adjustments, which will be conducive to financial stability in Asia and the world economy. As the short-term monetary policy strongly affects the domestic economy, it is often difficult to think of it in terms of cooperating with an overseas economy. For example, in September 2015, the U.S. FOMC did not take into account the situation of the overseas economy in deciding to raise interest rates. However, the risk of the United States and China not cooperating in these matters is evident. Face-to-face talks between the two economic giants through their annual S\&ED have become indispensable ingredients for a stable world economy. For even without a stable RMB, confidence that the exchange rate is geared toward a stable or appropriate level will reassure Asian and the world markets. 